\title{
Role of Sentinel Lymph Node Biopsy During Contralateral Prophylactic Mastectomy
}

\author{
Kontralateral Profilaktik Mastektomide Sentinel Lenf Nodu Biyopsisinin Yeri
}

\author{
(1) Halil Kara1, (1) Akif Enes Arıkan², (1) Onur Dülgeroğlu¹, (D) Cihan Uras² \\ 1 Acıbadem Mehmet Ali Aydınlar University, Vocational School of Health Sciences, ístanbul, Turkey \\ ${ }^{2}$ Acıbadem Mehmet Ali Aydınlar University, Vocational School of Medicine, Department of General Surgery, İstanbul, Turkey
}

\begin{abstract}
Introduction: Contralateral prophylactic mastectomy (CPM) is the removal of the opposite breast with the aim of risk reduction in cases of unilateral breast carcinoma. Routine use of sentinel lymph node biopsy (SLNB) at the time of CPM is controversial due to low occult breast cancer risk. This study aims to determine the rate of occult breast carcinoma and to evaluate whether SLNB should be performed during CPM.

Methods: Ninety-four patients who underwent CPM between 2009 and 2018 were evaluated retrospectively. Occult breast carcinoma detection rate and approach to axilla were evaluated.

Results: Occult invasive breast carcinoma was detected in three patients (3.2\%): two invasive ductal carcinoma and one multifocal invasive lobular carcinoma. Axillary staging was performed in second session. SLNB was performed in two patients and a micro-metastasis in one of four sentinel lymph nodes (SLN) was detected in one patient. Axillary lymph node dissection was performed in one patient in whom SLN was not detected.

Conclusion: SLNB can be performed in patients with suspicious lesion in the absence of biopsy or in patients with high-risk of occult breast cancer (postmenopausal, high Gail score, lobular histology, multi-centric tumor, ipsilateral high-risk lesion); however, routine SLNB use during CPM is not recommended in patients with no risk. SLNB in second session by intradermic radioisotope injection in case of occult carcinoma can be an alternative solution to axillary staging.
\end{abstract}

Keywords: Sentinel lymph node biopsy, prophylactic mastectomy, breast cancer

\section{öZ}

Amaç: Kontralateral profilaktik mastektomi (KPM), tek taraflı meme kanseri saptanan hastalarda risk azaltılması amacıyla karșı memenin alınmasıdır. Okült meme kanseri riskinin düşük olması nedeni ile KPM sırasında rutin sentinel lenf nodu biyopsisi (SLNB) kullanımı tartıșmalıdır. Bu çalıșmada okült meme kanseri saptama oranı ve KPM sırasında SLNB gerekliliğinin araștırılması hedeflenmektedir.

Yöntemler: 2009 ile 2018 yılları arasında KPM uygulanan 94 hastanın verileri retrospektif olarak incelendi. Okült meme kanseri saptanma oranı ve aksillaya yaklaşım değerlendirildi.

Bulgular: Üç $(\% 3,2)$ hastada okült invazif meme kanseri saptandı: iki invazif duktal karsinom ve bir multifokal invazif lobular karsinom. Aksiller evreleme ikinci seansta gerçekleștirildi. İi hastaya SLNB uygulandı ve hastaların birinde dört sentinel lenf nodunun (SLN) birinde mikrometastaz saptandı. SLN bulunamayan bir hastaya ise aksiller lenf nodu diseksiyonu uygulandı.

Sonuç: Biyopsi bulunmaksızın șüpheli lezyonu olan hastalara veya okült meme kanseri için yüksek riskli hastalara (postmenapozal, yüksek Gail skoru, lobular histoloji, multisentrik tümör, ipsilateral yüksek riskli lezyon) SLNB uygulanabilir. Bununla birlikte KPM sırasında rutin SLNB uygulaması önerilmemektedir. İkinci seansta intradermik radyoizotop enjeksiyonu ile SLNB yapılması okült meme kanserinde Aksiller evreleme için bir alternatif olabilir.

Anahtar Kelimeler: Sentinel lenf nodu biyopsisi, profilaktik mastektomi, meme kanseri

\section{Introduction}

Contralateral prophylactic mastectomy (CPM) is the removal of the opposite breast with the aim of risk reduction in cases of unilateral breast carcinoma. Patients with histories of breast carcinoma in one breast have an estimated risk of about $0.5 \%$ per year for developing contralateral breast cancer with a cumulative risk of about $6.9 \%$ at 10 years $(1,2)$. This rate increases in high-risk patients, such as breast cancer gene (BRCA) carriers. The risk of breast cancer can be reduced by $90 \%$ to $95 \%$ with CPM (3).
Address for Correspondence/Yazıșma Adresi: Halil Kara MD, Acıbadem Mehmet Ali Aydınlar University, Vocational

School of Health Sciences, İstanbul, Turkey

Phone: +90 5326073933 E-mail: halil.kara@acibadem.edu.tr ORCID ID: orcid.org/0000-0002-1527-7155

Cite this article as/Atıf: Kara H, Arıkan AE, Dülgeroğlu 0, Uras C. Role of Sentinel Lymph Node Biopsy During Contralateral Prophylactic Mastectomy. İstanbul Med J 2020; 21(2): 97-103.
Received/Geliș Tarihi: 06.11.2019 Accepted/Kabul Tarihi: 04.02.2020

(C) Copyright 2020 by the University of Health Sciences Turkey, Istanbul Training and Research Hospital/Istanbul Medical Journal published by Galenos Publishing House.

(C) Telif Hakkı 2020 Sağıı Bilimleri Üniversitesi Istanbul Ĕgitim ve Araştırma Hastanesi/Istanbul Tıp Dergisi, Galenos Yayınevi tarafından basılmıștır. 
With increased breast cancer awareness and use of genetic tests, the use of CPM has become more popular. According to the review of the Surveillance, Epidemiology, and End Results database, there was an increase in CPM from 1.8\% to 4.5\% between 1998 and 2003 (4,5). However, in most patients, the risk of systemic metastasis from the index tumor is greater than the risk of contralateral breast cancer development, so no survival gains can be achieved with CPM and therefore, patient selection is important (6).

The patient's age, risk analysis, family history, genetic mutations, cosmetic concerns, or patient choice are important during decision making for undergoing (or not) CPM (7). Recommendations of the Society of Surgical Oncology can be summarized under three main headings (8):

1. Risk reduction: BRCA mutation or other genetic alterations, strong family history, high-risk lesions, such as atypical ductal hyperplasia.

2. Difficult surveillance: Clinically or radiologically dense breast tissue or diffuse micro-calcifications with negative biopsy.

3. Reconstructive issues: For symmetry or balance.

Occult breast cancer detection is an important issue for CPM. While occult breast malignancy risk varies between $0.5 \%$ and $8 \%$ in the literature, invasive disease detection rates are reported as $0.1 \%-3.5 \%(4,9-12)$. On the other hand, with the development of radiology, especially with the increase in the use of magnetic resonance imaging (MRI), the rate of occult malignancy detection rate decreases to $0.8 \%-2 \%$ (13).

Routine use of sentinel lymph node biopsy (SLNB) at the time of CPM is controversial due to occult breast cancer risk and morbidity. SLNB is routinely used for staging in patients with early stage breast carcinoma and has less complications than axillary lymph node dissection (ALND), especially in terms of lymphedema. However, many studies still report complications such as 5\% lymphedema risk, 3\% arm restriction, and 7\% axillary paresthesia $(9,14)$. Also, the increases in cost and patient anxiety are other factors that should be taken into consideration. On the other hand, when an occult invasive carcinoma is detected in patients who have undergone CPM, there is increased necessity for ALND and thus, morbidity increases.

This study aims to determine the rate of occult breast carcinoma and to evaluate whether SLNB should be performed during CPM.

\section{Methods}

A retrospective analysis of all patients with a diagnosed cancer in one breast, who underwent CPM between 2009 and 2018, was performed. All indications for CPM were included in this study. Patients younger than 18 years of age and patients with a history of breast cancer on the contralateral side were excluded from the study.

While all the patients were evaluated with both mammography and ultrasound, most of the patients had had breast MRI up to six months prior to surgery. Physical examination of the contralateral breast was negative in all of the patients. All of the patients underwent surgery by the same surgical team, and all specimens were evaluated by the same pathology team. All of the reconstructions were performed immediately with gel-based implants. CPM was performed as an immediate or delayed procedure. Routine SLNB was not performed during CPM.
Axillary staging was performed at the second session but only if the patient had occult invasive breast carcinoma. If occult carcinoma was detected, the radioisotope method via intradermal injection was used for SLNB. Mastectomy type was chosen according to patients' preferences and comorbidities.

Mastectomy specimens were sliced into $2 \mathrm{~mm}$-thick sections. Sliced specimens were first examined macroscopically, and then random sampling was done from four quadrants. Samples were also taken when suspicious areas were seen.

Age, type, CPM indications, presence of occult breast carcinoma, and approach to axilla were evaluated. Since the patients did not undergo routine SLNB, contralateral occult axillary lymph node (ALN) metastasis could not be evaluated.

All procedures performed in the study involving human participants were in accordance with the 1964 Helsinki declaration and its later amendments or comparable ethical standards. In addition, this study was approved by Ethic Committee of Acıbadem University on March 07, 2019 with number 2019-5/7. Informed consent was waived since the trial included retrospective data analysis.

\section{Statistical Analysis}

Statistical analysis program was not used to evaluate the study data. Continuous variables were expressed as median and categorical variables as percentage.

\section{Results}

Ninety-four patients who underwent CPM between 2009 and 2018 were evaluated. All of the patients were women. The median age was 43.7 (range: 28-78) years. Patient characteristics are summarized in Table 1. The most common indication for CPM was family history (Table 1). Thirteen patients underwent surgery after neoadjuvant chemotherapy due to local advanced breast cancer. While one patient preferred simple mastectomy and two patients preferred skin sparing mastectomy in order to sustain symmetry, the rest of the patients preferred nipple sparing mastectomy as the CPM procedure. CPM was performed immediately in $76(80 \%)$ patients and in $18(20 \%)$ patients as a delayed procedure.

Occult breast cancer was detected in four (4.2\%) patients (Table 2). One of these patients had ductal carcinoma in situ (DCIS), two patients had invasive ductal carcinoma (IDC), and one patient had multifocal invasive lobular carcinoma (ILC). Axillary staging was performed for three patients (3.2\%) with invasive occult malignancy in the second session with exception of the patient with DCIS. The radioisotope method was preferred for SLNB. After intradermic radioisotope injection, two of the three patients had sentinel lymph node(s) (SLN) in the preoperative lymphoscintigraphic examination, and SLNB was performed. ALND was performed in the patient in whom SLN was not detected; however, no metastasis was detected in ALND. Even though one of the patients who underwent SLNB had a micro-metastasis in one of four SLNs, no complete ALND was performed. The detection of occult breast cancer in the CPM did not alter the choice of patient treatment. One patient had chemotherapy because of the index tumor, while the other three patients received hormone therapy only. 
Breast MRI had been obtained for 66 (70\%) patients in the last six months. In 19 of 66 (29\%) patients, MRI revealed lesions on the contralateral side. In 13 (68\%) of these 19 patients, the lesions were defined as benign, and six (32\%) were evaluated with preoperative biopsies due to suspicious lesions. Biopsy results were benign, but in one (16.7\%) of the patients $(n=6)$ who underwent biopsy, occult IDC was detected in the final pathology. However, in two patients with occult carcinoma, there were no suspicious lesions on MRI.

In 28 (30\%) of 94 patients, breast MRIs had not been obtained. Only in one (3.6\%) of these 28 patients, the pathology report revealed occult breast carcinoma.

Sclerosing adenosis was the most common finding in final pathology. Histological findings in the CPM specimen are summarized in Table 3.

In the median 41 (range: 4-96) -month follow-up of patients ( $n=4,4.2 \%$ ) with occult breast carcinoma on the contralateral side, no recurrence or new tumor development was seen in both breasts, and no distant metastasis was detected. Of patients without occult carcinoma, only one patient died at the $36^{\text {th }}$ month of follow-up due to distant metastasis while five patients are still undergoing follow-up due to recurrence and three patients due to distant metastases.

\section{Discussion}

As breast cancer awareness increases, interest in CPM by both surgeons and patients has also increased. In general, survival gain cannot be achieved with CPM but can be applied especially in selected patient groups (8). CPM may be recommended for high-risk patients who have gene mutations, strong family history, and difficulty in radiological or clinical follow-up, and for symmetry, patient choice is also important. Anxiety about the potential development of contralateral breast cancer is a significant factor in patients' choice of CPM, especially in young patients with a long life expectancy (1).

In various publications, the risk of occult malignancy (in situ and invasive) varies between $0.5 \%$ and $8 \%$; however, the detection of occult invasive disease has been reported at the rate of $0.1-3.5 \%$. This rate can

\section{Table 1. Characteristics of the patients}

Age (years; median-range)

Menopausal status (n, \%)

Family history (n, \%)

Side of index tumor (n, \%)

Type of surgery $(n, \%)$

Stage of index tumor $(\mathrm{n}, \%$

Indications for contralateral prophylactic mastectomy $(\mathrm{n}, \%)$

\begin{tabular}{|c|c|}
\hline & $43.7(28-78)$ \\
\hline Premenopausal & $78(83 \%)$ \\
\hline Postmenopausal & $16(17 \%)$ \\
\hline Present & $31(33 \%)$ \\
\hline Absent & $63(67 \%)$ \\
\hline Right & $46(49 \%)$ \\
\hline Left & $48(51 \%)$ \\
\hline Simple mastectomy & $2(2 \%)$ \\
\hline Skin sparing mastectomy & $1(1 \%)$ \\
\hline Nipple sparing mastectomy & $91(97 \%)$ \\
\hline Early stage & $81(86 \%)$ \\
\hline Locally advanced & $13(14 \%)$ \\
\hline Family history & $23(24 \%)$ \\
\hline Dense breast tissue & $22(23 \%)$ \\
\hline Gene mutation & $13(14 \%)$ \\
\hline Lobular histology & $9(10 \%)$ \\
\hline Patient's choice & $9(10 \%)$ \\
\hline Multi-centric/focal malignancy & $8(9 \%)$ \\
\hline Symmetry & $4(4 \%)$ \\
\hline Young age (<35-year-old) & $4(4 \%)$ \\
\hline Recurrence & $2(2 \%)$ \\
\hline
\end{tabular}

Table 2. Characteristics of patients with occult contralateral breast carcinoma

\begin{tabular}{|c|c|c|c|c|c|c|c|c|}
\hline & Age (years) & $\begin{array}{l}\text { Indication for } \\
\text { CPM }\end{array}$ & $\begin{array}{l}\text { Side of index } \\
\text { tumor }\end{array}$ & $\begin{array}{l}\text { Histology of } \\
\text { occult tumor }\end{array}$ & $\begin{array}{l}\text { Type of } \\
\text { index tumor }\end{array}$ & $\begin{array}{l}\text { Stage of index } \\
\text { tumor }\end{array}$ & $\begin{array}{l}\text { Stage of } \\
\text { contralateral tumor }\end{array}$ & $\begin{array}{l}\text { Follow-up } \\
\text { (months) }\end{array}$ \\
\hline Case 1 & 56 & Patient's choice & Left & DCIS & DCIS & TisN0M0 & TisNO & 70 \\
\hline Case 2 & 54 & $\begin{array}{l}\text { Abnormal } \\
\text { findings in MRI }\end{array}$ & Left & IDC & IDC & T1N0M0 & T1N0 & 44 \\
\hline Case 3 & 43 & Family history & Left & LCIS & DCIS & T1N0M0 & T1Nmi & 38 \\
\hline Case 4 & 38 & Family history & Left & IDC & IDC & T2N1M0 & T1N0 & 22 \\
\hline
\end{tabular}

CPM: contralateral prophylactic mastectomy, DCIS: ductal carcinoma in situ, IDC: invasive ductal carcinoma, LCIS: lobular carcinoma in situ, MRI: magnetic resonance imaging 
be as high as 5\%-15\% in high-risk patients (3,4,9-12). In current study, the rate of occult malignancy was found to be $4.2 \%(n=4)$ while the rate of invasive carcinoma was found to be $3.2 \%(n=3)$. Yi et al. (6) found three independent factors that predicted occult malignancy in the contralateral breast: 1) ipsilateral invasive lobular histology; 2) ipsilateral

\section{Table 3. Pathological findings in contralateral prophylactic mastectomy specimens}

\begin{tabular}{|l|l|}
\hline & Number of patients (\%) \\
\hline Sclerosing adenosis & $29(30 \%)$ \\
\hline Stromal fibrosis & $15(16 \%)$ \\
\hline Normal findings & $15(16 \%)$ \\
\hline Fibroadenoma & $10(10.5 \%)$ \\
\hline Apocrine metaplasia & $6(6.5 \%)$ \\
\hline Intraductal papilloma & $4(4 \%)$ \\
\hline Florid intraductal hyperplasia & $3(3 \%)$ \\
\hline Flat epithelial hyperplasia & $3(3 \%)$ \\
\hline Atypic ductal/lobular hyperplasia & $2(2 \%)$ \\
\hline Lobular carcinoma in situ & $2(2 \%)$ \\
\hline Invasive ductal carcinoma & $2(2 \%)$ \\
\hline Invasive lobular carcinoma & $1(1 \%)$ \\
\hline Ductal carcinoma in situ & $1(1 \%)$ \\
\hline Tubular adenoma & $1(1 \%)$ \\
\hline
\end{tabular}

multi-centric tumor; and 3) a 5-year Gail risk score $\geq 1.67 \%$. In that study, multivariate analysis also revealed that age $\geq 50$ years at the time of the initial cancer diagnosis and an additional ipsilateral moderate to high risk pathology were independent predictors of moderate to high-risk histological findings in the contralateral breast (6). Boughey et al. (9) reported that older age (>60 years), postmenopausal status, and lobular type malignancy (ILC/lobular carcinoma in situ) were associated with occult breast cancer risk.

Today many surgeons use MRI for the evaluation of the breast before prophylactic mastectomy (PM). When compared to mammography, MRI has been shown to increase the detection rate of small cancers, especially in high-risk patients (3). Incidental contralateral breast cancer can be detected in $5 \%$ of patients with MRI $(15,16)$. On the other hand, false negative and positive rates of MRI should be kept in mind. There are different opinions about the use of MRI in the detection of occult breast cancer in high-risk patients in addition to effects on decision making for selective SLNB indications in patients undergoing CPM. Black et al. (3) concluded that MRI significantly caused an increase in diagnostic costs and missed most occult cancers in PMs. In contrast, McLaughlin et al. (13) and Freitas et al. (16) concluded that MRI accurately ruled out the presence of invasive cancer in PM. While the use of MRI in cases without BRCA mutation is controversial due to costs and detection rates, it is recommended in patients with the BRCA mutation (17). In the current study, six of 66 patients with MRI had suspicious lesions

Table 4. Published reports investigating sentinel lymph node involvement in bilateral prophylactic mastectomy and/or contralateral prophylactic mastectomy (2000-2018)

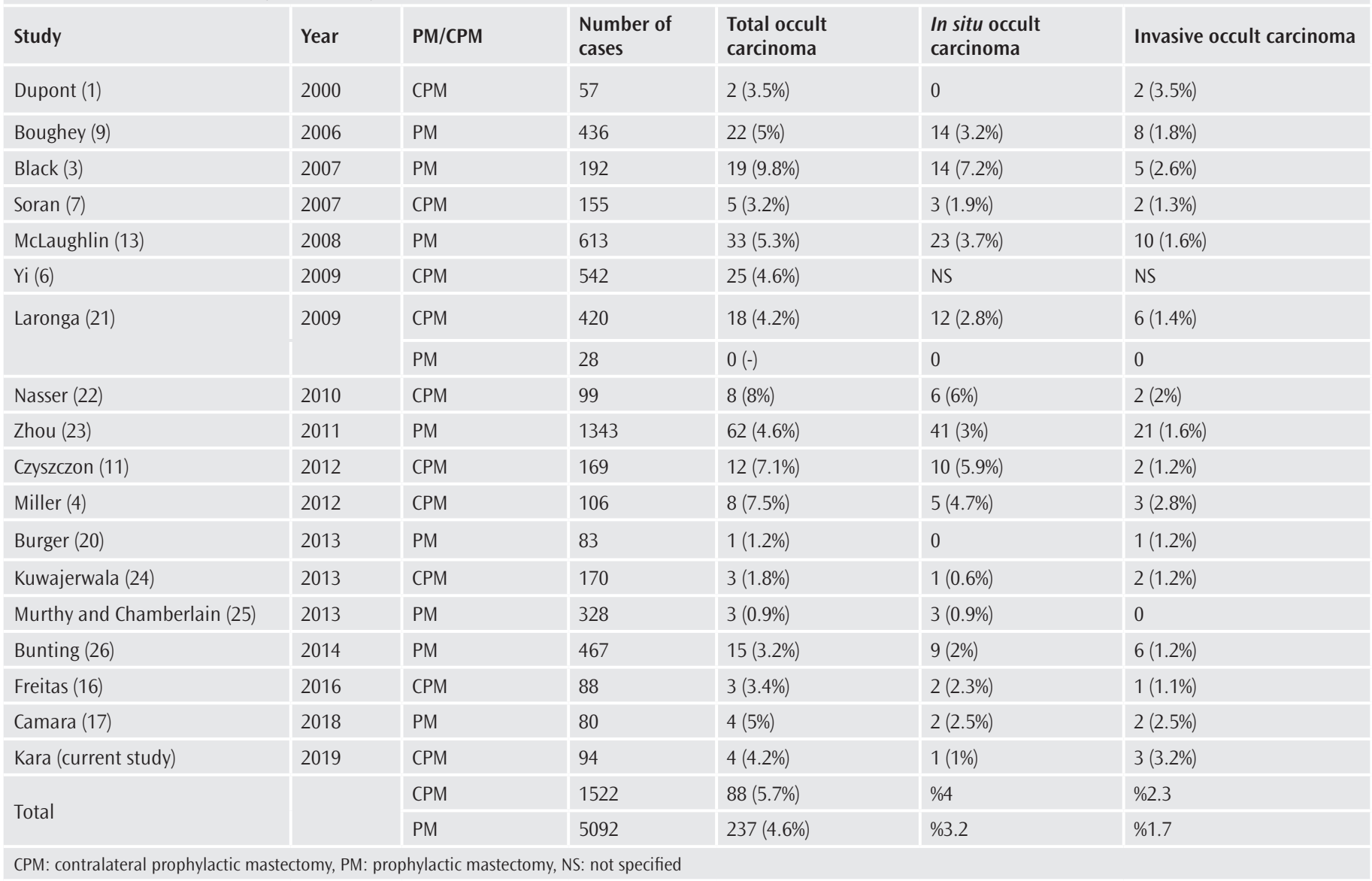


Table 5. Clinical arguments for and against the adoption of sentinel lymph node biopsy in prophylactic mastectomy

Arguments supporting the adoption of SLNB in PM

1. The morbidity of SLNB is low and can be safely performed with mastectomy.

2. Axillary lymph node dissection can be avoided if occult invasive breast carcinoma is detected by simultaneous SLNB.

3. SLNB may detect occult contralateral nodal disease that has metastasized from the index tumor.

4. With simultaneous SLNB, the patient will not be exposed to a second operation and the risk of anesthesia.

5. Performing axillary staging in second session may cause delay in the treatment of patient.
Arguments against the adoption of SLNB in PM

1. The risk of occult invasive carcinoma is very low.

2. The detected occult lesions are early lesions (Ti or T1a-b) and the risk of SLN positivity is very low.

3. The effect of occult malignancies on the treatment is very low.

4. SLNB has also complications.

5. Cost increases with routine SLNB.

6. The operation time increases.

7. The aesthetic importance of incision required for SLNB.

8. In appropriate cases SLNB can be performed after mastectomy.

SLNB: sentinel lymph node biopsy, PM: prophylactic mastectomy

and were evaluated with preoperative biopsy. While all of the biopsies were benign, occult IDC was detected only in one patient in the final pathology. The identification rate of an occult carcinoma by MRI prior to CPM was quite low at $1.5 \%(1 / 66)$ in contrast to the current literature $(13,16)$. Thus, MRI did not affect the decision of SLNB use in CPM.

Another issue that should be considered in the case of occult carcinoma is axillary staging. Patients with early -stage breast carcinoma routinely undergo SLNB for axillary staging since SLNB was first reported in the early 1990s (1). Although SLNB has lower complication rates when compared to ALND, 5.6\% lymphedema and other minor complications are still observed. In addition, simple allergic (1\%-2\%) or anaphylactic reactions (0.25\%-0.5\%) can occur due to the blue dye. A false negative ratio of $8.4 \%(0 \%-29 \%)$ must also be kept in mind $(18,19)$.

Routine use of SLNB at the time of CPM is controversial. Table 4 summarizes the studies covering occult breast carcinoma detection rates in PM or CPM without contralateral or bilateral discrimination. The surgeons using routine SLNB during CPM suggest that SLNB cannot be performed after mastectomy, so in case of occult invasive malignancy at CPM, ALND will be mandatory at the second session, which may cause an increase in morbidity. In addition, many authors suggest that they do not observe lymphedema or the risk is similar in the cases in which SLNB is not performed $(1,4,20)$. They also state that SLNB is helpful to find possible cross-metastases from index tumor (1).

The group that does not recommend SLNB during CPM states that the risks of occult invasive carcinoma detection and SLN positivity in these tumors are too low because of the very early state. They also report that there is comorbidity associated with SLNB in the guidelines and that routine use is not appropriate. Another point is that the detection of occult breast cancer in CPM has minimal effects on the patient's treatment. Table 5 summarizes the clinical arguments for and against the adoption of SLNB in PM.

There are three prominent studies suggesting routine SLNB use during CPM. Dupont et al. (1) found two invasive occult carcinomas (3.5\%) and two occult axillary metastases; however, patients with occult breast carcinoma did not represent metastasis in SLNB. They suggested SLNB because of lack of SLNB-induced lymphedema and change in treatment of four (7\%) patients. Miller et al. (4) found three occult invasive carcinomas (2.8\%) in 106 CPMs and micro-metastasis only in one patient during SLNB. Although the risk of lymphedema was high in the group with ALND, they suggested SLNB use during CPM because they did not find any differences in lymphedema between the groups with and without SLNB. Burger et al. (20) found only one occult ILC and three lobular in situ neoplasms in 83 PMs. They suggested SLNB because they did not see lymphedema in any patient and thought that adding SLNB did not prolong the duration of operation.

On the other hand, there are many studies in which routine SLNB during CPM is not recommended $(3,6,7,9,11,13,16,17,21-26)$. In the meta-analysis by Zhou et al. (23), the occult breast carcinoma rate was found to be $1.6 \%$ in 1343 PMs. Four of the patients with invasive occult carcinoma and one of the patients with DCIS were found to have SLN positivity while 19 occult ALN metastases were found. Benefits from SLNB were obtained in 36 (2.8\%) patients (17 SLN negative patients and 19 patients with occult lymph node metastasis). However, it should be noted that $12(50 \%)$ of the patients with positive SLNB had advanced disease. Thus, they did not recommend routine SLNB. In most of the studies that identified occult lymph node metastasis in the contralateral axilla, it is mentioned that these metastases are probably due to advanced index tumor $(11,21,22)$.

When studies involving only CPM are considered, the following outputs have yielded several findings. In the study of Yi et al. (6), the ratio of occult carcinoma was found to be $4.6 \%$ in the 542 CPMs although invasive/in situ discrimination was not performed. Laronga et al. (21) found this rate of invasive occult carcinoma to be $1.6 \%$ in their studies involving 420 CPMs. Occult SLN metastasis was detected in seven patients, and all of these patients presented with locally advanced breast cancer. In the same study, it was concluded that SLNB should not be indicated in patients who underwent bilateral PM or CPM associated with early stage disease. However, patients with locally advanced primary breast cancer had a significantly increased risk of contralateral occult ALN metastasis due most likely to crossover metastasis; this selected group of patients may benefit from SLNB. In another study conducted by Soran et al. (7), two invasive occult carcinomas (1.3\%) were found in 155 CPMs, and two occult ALN metastases were found in patients who underwent surgery 
for recurrent invasive carcinoma. Even though lymphedema was not seen in these patients, routine SLNB was not suggested as the risk of occult breast cancer was low. In the hypothetical cohort introduced by Boughey et al. (10), in cases in which the incidence of occult breast cancer was taken as $1.9 \%$, the rate of SLN detection, the ratio of SLN positivity, and ratio of occult axillary metastasis were considered, and those complications would be seen in 680 of 10,000 patients with routine SLNB, only in 137 patients ALND could be avoided. In this study, three invasive occult carcinomas were detected among 94 CPMs. While SLNB was performed as second sessions in two patients, ALND was performed only in the patient in whom SLN was not found. In a total of 91 patients, SLNB and related complications were avoided and benefits from routine use of SLNB could be gained in only one patient. In a hypothetical proposition in which routine SLNB was performed during CPM and when the complication rate of SLNB was taken as 5\%, there may be have been possible complications in five patients due to routine SLNB use; however, even if the SLN detection rate was accepted as $100 \%$, ALND could have been avoided in only one patient.

The American Society of Breast Surgeons Consensus Meeting suggest that routine use of SLNB at the time of CPM is not necessary (12). Higher risks of occult malignancy in CPM are related to postmenopausal status, triple-negativity, locally advanced stage, and inflammatory or invasive lobular histology. They recommend biopsy if a suspicious lesion is detected in the preoperative MRI. Murphy et al. (27) investigated the role of intraoperative pathological examination of the resected breast tissue in PM. In 1900 cases (1410 CPM, 490 PM), 58 occult malignancies (32 invasive, 26 DCIS) were detected. Of these 58 cases, occult malignancies were found during surgery in 44 cases, and SLNB was performed. Facilitation of intraoperative pathology may prevent overtreatment in patients who have not been diagnosed with occult malignancy. Thus, they suggest SLNB use according to the results of the intraoperative pathological examination.

The most important consideration for authors who propose SLNB during CPM is that SLNB cannot be performed after a mastectomy in the case of an occult malignancy. Although the performance of SLNB in second session after mastectomy has not been extensively studied, a few case reports and very small series have reported a success rate of $65 \%$ to $100 \%$ (28-30). In the current study, SLN was detected by intradermic radioisotope injection in two of the three patients who underwent axillary staging. However, the studies related to SLNB after mastectomy has low power, and SLNB after mastectomy can be considered as an alternative solution for staging in selected cases.

\section{Conclusion}

The evaluation of the patients who are candidates for CPM is very important. If a suspicious contralateral breast lesion is found, a biopsy should be performed prior to surgery. SLNB can be performed in patients with suspicious lesions in the absence of biopsy or in patients with high risk for occult breast cancer (postmenopausal, high Gail score, lobular histology, multi-centric tumor, ipsilateral high-risk lesion). SLNB should also be considered when a second session would not be welcome, such as in cases of anticoagulant use, having comorbidities that would increase the risk factor for anesthesia, and local advanced breast cancer (due to cross-metastasis risk). However, routine SLNB use during CPM in patients with no risk is not recommended.

\section{Ethics}

Ethics Committee Approval: In addition, this study was approved by Ethic Committee of Acıbadem University on March 07, 2019 with number 2019-5/7.

Informed Consent: Informed consent was waived since the trial included retrospective data analysis.

Peer-review: Externally and internally peer-reviewed.

Authorship Contributions: Concept - H.K., A.E.A., O.D., C.U.; Design H.K., A.E.A., O.D., C.U.; Data Collection or Processing - H.K., A.E.A., O.D., C.U.; Analysis or Interpretation - H.K., A.E.A., O.D., C.U.; Literature Search - H.K., A.E.A.; Writing - H.K., A.E.A., O.D., C.U.

Conflict of Interest: No conflict of interest was declared by the authors.

Financial Disclosure: The authors declared that this study received no financial support.

\section{References}

1. Dupont EL, Kuhn MA, McCann C, Salud C, Spanton JL, Cox CE. The role of sentinel lymph node biopsy in women undergoing prophylactic mastectomy. Am J Surg 2000; 180: 274-7.

2. Kantor O, Chang C, Bleicher RJ, Moran M, Connolly JL, Kurtzman SH, et al; National Accreditation Program for Breast Centers Data Working Group. Physician Knowledge of Breast Cancer Recurrence and Contralateral Breast Cancer Risk is Associated with Increased Recommendations for Contralateral Prophylactic Mastectomy: a Survey of Physicians at NAPBC-Accredited Centers. Ann Surg Oncol 2019; 26: 3080-8.

3. Black D, Specht M, Lee JM, Dominguez F, Gadd M, Hughes K, et al. Detecting occult malignancy in prophylactic mastectomy: preoperative MRI versus sentinel lymph node biopsy. Ann Surg Oncol 2007; 14: 2477-84.

4. Miller CL, Specht MC, Skolny MN, Jammallo LS, Horick N, O'Toole J, et al. Sentinel lymph node biopsy at the time of mastectomy does not increase the risk of lymphedema: implications for prophylactic surgery. Breast Cancer Res Treat 2012; 135: 781-9

5. Tuttle TM, Habermann EB, Grund EH, Morris TJ, Virnig BA. Increasing use of contralateral prophylactic mastectomy for breast cancer patients: a trend toward more aggressive surgical treatment. J Clin Oncol 2007; 25: 5203-9.

6. Yi M, Meric-Bernstam F, Middleton LP, Arun BK, Bedrosian I, Babiera GV, et al. Predictors of contralateral breast cancer in patients with unilateral breast cancer undergoing contralateral prophylactic mastectomy. Cancer 2009; 115: 962-71.

7. Soran A, Falk J, Bonaventura M, Keenan D, Ahrendt G, Johnson R. Is routine sentinel lymph node biopsy indicated in women undergoing contralateral prophylactic mastectomy? Magee-Womens Hospital experience. Ann Surg Oncol 2007; 14: 646-51.

8. Giuliano AE, Boolbol S, Degnim A, Kuerer H, Leitch AM, Morrow M. Society of Surgical Oncology: position statement on prophylactic mastectomy. Approved by the Society of Surgical Oncology Executive Council, March 2007. Ann Surg Oncol 2007; 14: 2425-7.

9. Boughey JC, Khakpour N, Meric-Bernstam F, Ross MI, Kuerer HM, Singletary SE, et al. Selective use of sentinel lymph node surgery during prophylactic mastectomy. Cancer 2006; 107: 1440-7. 
10. Boughey JC, Cormier JN, Xing Y, Hunt KK, Meric-Bernstam F, Babiera GV, et al. Decision analysis to assess the efficacy of routine sentinel lymphadenectomy in patients undergoing prophylactic mastectomy. Cancer 2007; 110: 2542-50.

11. Czyszczon IA, Roland L, Sahoo S. Routine prophylactic sentinel lymph node biopsy is not indicated in women undergoing prophylactic mastectomy. J Surg Oncol 2012; 105: 650-4.

12. BougheyJC, Attai DJ, Chen SL, Cody HS, DietzJR, Feldman SM, et al. Contralateral Prophylactic Mastectomy Consensus Statement from the American Society of Breast Surgeons: Additional Considerations and a Framework for Shared Decision Making. Ann Surg Oncol 2016; 23: 3106-11.

13. McLaughlin SA, Stempel M, Morris EA, Liberman L, King TA. Can magnetic resonance imaging be used to select patients for sentinel lymph node biopsy in prophylactic mastectomy? Cancer 2008; 112: 1214-21.

14. Lucci A, McCall LM, Beitsch PD, Whitworth PW, Reintgen DS, Blumencranz PW, et al. Surgical complications associated with sentinel lymph node dissection (SLND) plus axillary lymph node dissection compared with SLND alone in the American College of Surgeons Oncology Group Trial Z0011. J Clin Oncol 2007; 25: $3657-63$

15. Liberman L, Morris EA, Kim CM, Kaplan JB, Abramson AF, Menell JH, et al. MR imaging findings in the contralateral breast of women with recently diagnosed breast cancer. AJR Am J Roentgenol 2003; 180: 333-41.

16. Freitas V, Crystal P, Kulkarni SR, Ghai S, Bukhanov K, Escallon J, et al. The value of breast MRI in high-risk patients with newly diagnosed breast cancer to exclude invasive disease in the contralateral prophylactic mastectomy: Is there a role to choose wisely patients for sentinel node biopsy? Cancer Med 2016; 5: 1031-6.

17. Camara S, Pereira D, Andre S, Mira B, Vaz F, Oom R, et al. The Use of Sentinel Lymph Node Biopsy in BRCA1/2 Mutation Carriers Undergoing Prophylactic Mastectomy: A Retrospective Consecutive Case-Series Study. Int J Breast Cancer 2018; 2018: 1426369

18. Disipio T, Rye S, Newman B, Hayes S. Incidence of unilateral arm lymphoedema after breast cancer: a systematic review and meta-analysis. Lancet Oncol 2013; 14: 500-15.

19. Lyman GH, Giuliano AE, Somerfield MR, Benson AB, 3rd, Bodurka DC, Burstein $\mathrm{HJ}$, et al. American Society of Clinical Oncology guideline recommendations for sentinel lymph node biopsy in early-stage breast cancer. J Clin Oncol 2005; 23: $7703-20$.

20. Burger A, Thurtle D, Owen S, Mannu G, Pilgrim S, Vinayagam R, et al. Sentinel lymph node biopsy for risk-reducing mastectomy. Breast J 2013;19:529-32.

21. Laronga C, Lee MC, McGuire KP, Meade T, Carter WB, Hoover S, et al. Indications for sentinel lymph node biopsy in the setting of prophylactic mastectomy. J Am Coll Surg 2009; 209: 746-52; quiz 800-1.

22. Nasser SM, Smith SG, Chagpar AB. The role of sentinel node biopsy in women undergoing prophylactic mastectomy. J Surg Res 2010; 164: 188-92.

23. Zhou WB, Liu XA, Dai JC, Wang S. Meta-analysis of sentinel lymph node biopsy at the time of prophylactic mastectomy of the breast. Can J Surg 2011; 54: 300-6.

24. Kuwajerwala NK, Dekhne NS, Pentiak PA, Fend D, Callahan RE, Amine M, et al. Sentinel lymph node biopsy in contralateral prophylactic mastectomy: are we overtreating? Experience at a tertiary care hospital. Clin Breast Cancer 2013; 13: $287-91$

25. Murthy V, Chamberlain RS. Prophylactic mastectomy in patients at high risk: is there a role for sentinel lymph node biopsy? Clin Breast Cancer 2013; 13: 180-7.

26. Bunting PW, Cyr AE, Gao F, Margenthaler JA. Sentinel lymph node biopsy during prophylactic mastectomy: is there a role? J Surg Oncol 2014; 109: 74750 .

27. Murphy BL, Glasgow AE, Keeney GL, Habermann EB, Boughey JC. Selective Use of Sentinel Lymph Node Surgery in Patients Undergoing Prophylactic Mastectomy Using Intraoperative Pathology. Ann Surg Oncol 2017; 10: 3032-7.

28. Karam A, Stempel M, Cody HS, Port ER. Reoperative sentinel lymph node biopsy after previous mastectomy. J Am Coll Surg. 2008; 207: 543-8.

29. Intra M, Veronesi P, Gentilini OD, Trifiro G, Berrettini A, Cecilio R, et al. Sentinel lymph node biopsy is feasible even after total mastectomy. J Surg Oncol 2007; 95: 175-9.

30. Vicente DA, Henry LR, Hahm G, Soballe PW, Smart D. Axillary sentinel lymph node biopsy after mastectomy: a case report. World J Surg Oncol 2010; 8: 59. 